\title{
From atypical to paradigmatic? The relevance of the study of artistic work for the sociology of work ${ }^{*}$
}

\author{
Pierre Bataille $^{* *}$, Sonia Bertolini ${ }^{* * *}$, \\ Clementina Casula ${ }^{* * * *}$, Marc Perrenoud ${ }^{* * * * *}$
}

\begin{abstract}
Artistic work has been mainly defined in modern industrial societies by its atypical features vis à vis standard productive work; in post-industrial societies, however, it becomes increasingly considered as paradigmatic of a new "creative class", including workers within a variety of knowledge and creative sectors. The article discusses this paradox offering a sample of key contributions offered by sociology to the study of artistic work and professions, useful to uncover the ideological bias hidden behind the supposedly new significance of artistic work within creative economies. It thus introduces and discusses the essays collected in the special issue linking them to the ongoing changes on the nature of work in contemporary societies.

\footnotetext{
** Article submitted: 17/03/2020. Article accepted: 12/05/2020. Although the article is the result of shared reflections among the authors and has been collectively revised, the original writing of the paragraphs can be attributed in the following way: P. Bataille ( $\$ 2.4$, first half of §3), S. Bertolini (§2.3, second half of §3), C. Casula, (§1, §2.1), M. Perrenoud (§2.3, §4). We wish to thank all anonymous referees, Howard Becker and Marco Santoro for section editor for their support throughout the publication process.

${ }^{* * *}$ University of Grenoble-Alpes. Email: pierre.bataille@univ-grenoble-alpes.fr.

${ }^{* * * * *}$ University of Turin. Email: sonia.bertolini@unito.it.

${ }^{* * * * * * * *}$ University of Cagliari. Email: clcasula@unica.it

${ }^{* * * * * * * * * *}$ University of Lausanne. Email: marc.perrenoud@unil.ch.
} their precious advices on the articles and our foreword and the journal's editorial board and
\end{abstract}


Keywords: sociology of work; artistic work and professions; gig economy; precariat

\section{Da atipico a paradigmatico? La rilevanza dello studio del lavoro artistico per la sociologia del lavoro}

\section{Riassunto}

Il lavoro artistico è stato principalmente definito nelle moderne società industriali per le sue caratteristiche atipiche rispetto al lavoro standard produttivo; nelle società post-industriali, invece, è spesso presentato come paradigmatico di una nuova "classe creativa", che ricomprende i lavoratori nei settori della conoscenza e creatività. L'articolo discute questo apparente paradosso facendo riferimento ad alcuni contributi chiave della sociologia allo studio del lavoro e delle professioni artistiche, utili a svelare il pregiudizio ideologico nascosto dietro alla nuova centralità del lavoro artistico nelle economie creative. Introduce poi e discute gli articoli raccolti all'interno del numero monografico, ricollegandoli ai mutamenti nella natura del lavoro nelle società contemporanee.

Parole chiave: sociologia del lavoro; lavoro e professioni artistiche; gig economy; classe dei precari

\section{The shifting position of artistic work}

Artistic work has represented a puzzling conundrum for social scientists, given its liminoid positioning between the spheres of labour and leisure and its atypical features vis à vis standard alienated and productive work of industrial societies (Turner, 1974, Freidson, 1986). However, with the development of post-industrial capitalism, focussing on the exploitation of knowledge and creativity, scholars increasingly refer to artistic work as paradigmatic of a new "creative class", including a variety of workers from different sectors (Howkins, 2001, Florida, 2002). Not differently from "ordinary artists" (Perrenoud and Bois, 2017), representing on average the occupational category of artists (Menger, 1999, 2002), knowledge and creative workers are involved in non-routine activities, often implying emotional involvement easily translated in practices of self-exploitation, they earn less than occupational groups with comparable education, training and age, they presents higher levels of self-employment, unemployment and underemployment and manage precarious occupational 
condition through strategies of job diversification and the development of "portfolio careers" (Murgia, Maestripieri and Armano, 2016). Artistic work has also been called upon to describe the occasional nature of work within digital platforms, acting as intermediary between supply and demand for labour, also referred to with the expression "gig economy", evoking to the form of engagement for a single performance widely diffused among popular musicians (Cloonan and Williamson, 2017; Giorgiantonio and Rizzica, 2018).

We share the opinion that the debate celebrating artistic work as paradigmatic of a new creative economy or cognitive capitalism (Boutang, 2007) ambiguously posits the equivalence among two idealtypes of artist, with a quite different symbolic and economic positioning. In modern Western industrial societies, the atypical status of the artistic occupation vis à vis standard work was reconfigured building on an elitist idea of the arts, increasingly integrated within legitimated fields of culture, depicting an ideal of the charismatic artist as an individual owning an exclusive talent. This ideal, while based on a myth often far from reality, allowed the artistic occupation to find a shelter from the odds of free market economy in a socially recognised distinctive professional identity (Freidson, 1989, Moulin, 1992, Lehmann, 2005). The paradigmatic condition of the artist following the move from industrial to creative economies or platform capitalism, however, mostly refers to a type of "ordinary artist" (Becker, 1951; Perrenoud, 2007), neither rich nor famous, exposed to precarious and intermittent working conditions, engaged in heteronomous activities (Perrenoud and Bois, 2017), to the musicians of the "bars and clubs" rather than "the gentlemen of the musical elite" (Cloonan and Williamson, 2017). While those two idealtypes of workers within artistic labour markets share a relation to their respective arts worlds and to the mechanisms and conventions organising them (Becker, 1986), they experience quite different occupational conditions in terms of remuneration, job security, social prestige, work identity.

In face of this fundamental conceptual ambiguity, we found it useful to open the issue retracing some key elements offered by sociology to the study of artistic work, from the mechanisms contributing to establish the romantic myth of the artist as a charismatic individual (§2.1), to the disclosure of the prevalent collective and ordinary dimension of artistic work (§2.2); from the discovery of the strength of the informal ties organizing artistic careers and labour markets (§2.3), to the recognition of the influence of institutional contexts - especially at the nation-state level in regulating them (§2.4). We shall then present the six essays collected in 
the special issue (§3) and conclude with some general reflections on the implications deriving from the ideological shift celebrating artists as a paradigmatic case of workers in creative economies (§4).

\section{The contribution of sociology to the study of artistic work}

The belief that success and recognitions achieved by artists are mainly, when not exclusively, related to their exceptional talent, creativity and genius, understood as largely innate characteristics, is deeply rooted within modern Western societies. This partly explains the relative lack of attention traditionally given by the social sciences to the study of educational and working processes within this field, where the presupposed exclusivity of artistic trajectories hinders their reading in socio-institutional terms. For a long time, histories of the arts were considered the only legitimate discourses on artistic productions, mainly conceived as symbols and object of exegeses, savant and daring interpretations by aesthetics' specialists (critics, historians, gallerists, impresarios), mundane agents functional in transmuting the "pure" work of arts into objects of market trade with a price.

Influenced throughout the first half of the $20^{\text {th }}$ century by the positivistic tradition, sociology neglected the study of the arts or other aspects of culture requiring evaluative stands (Zolberg 1990, p. 23), although with some noticeable exceptions (Simmel, 1911; Weber, 1921). From the second half of the $20^{\text {th }}$ century, however, it increasingly draws its attention to the historical processes establishing the myth of the artist as "uncreated creator" (Bourdieu, 1980) and the mechanisms defining the "social magic" (Lahire, 2015) of artistic production and starts looking at artist's activities as ordinary work defined by collective action and regulated by specific labour market mechanisms, often significantly shaped by State intervention.

\subsection{The historical disembeddedness of the arts from the field of work}

Social studies on artistic work have shown how the construction and establishment of the figure of the artist as a charismatic individual creator is part of a wider process occurring in modern Western societies, aimed at the valorisation of the artistic occupation. Historical turning points in its path were thus identified, taking variations in routes depending on the artistic 
sector or the institutional context ${ }^{1}$. It is mainly during the Italian Renaissance that the artist's activities start being differentiated from the manual trades of the mechanical arts, practiced within craft corporations, and attributed the theoretical dignity of the liberal arts (Moulin, 1986, Prandstraller, 1986, Freidson, 1989). In Middle Age Europe, in fact, artists worked collectively in workshops, several hands painting on the same canvas or carving the same sculpture, apprentices doing some parts and masters the others, the artwork being not signed by a single author. Artistic work was mostly a matter of efficiency in the response to a command for a piece useful for extrinsic purposes, as largely in the case of what we call craftsmanship (Becker, 1982; Sennett, 2008).

Between the $16^{\text {th }}$ and $17^{\text {th }}$ centuries several social processes contribute in moving the social reality of art and artists to a new dominant paradigm, that can be defined as the "classical age". From Renaissance to the modern era, more or less at the same time in different countries in Europe, religion (especially Catholicism) steps back and science advances, the bourgeoisie arises as a new dominant social group, and arts are not any longer mainly seen as a tool to educate the masses. The idea of art as a specific field of knowledge based on a corpus of scientific rules grounding specialized expertise and techniques develops gradually. In the process of autonomization of the artistic sphere, the "academization of arts" through the creation of institutes for vocational training (Academies or Conservatoires) represents a fundamental step towards professional recognition of artistic occupations, allowing to establish the autonomy of artistic rules from religious and political subordination and to enhance the canonization of artistic knowledge as high culture within legitimated systems of cultural classification ${ }^{2}$.

${ }^{1} 1$. Tessarolo (2014) proposes the periodisation based on the idealtype offered by Burke (1979), referring to the case of visual artists in Italy, similar to that proposed by Moulin (1986) for visual artists in France. For the case of musicians see, among others: Weber (1992, 1994), Frederikson and Rooney (1990), Bellini (2005).

${ }^{2} 2$. Moulin, 1992, Pierre, 1990, Laillier, 2017, Casula, 2018.a. One of the main strategies in the process of professionalization of vocational occupations has been that of making them worthy of bourgeois aspirations, legitimating them to high culture (as opposed to skilled craft), through the association with a scientific corpus of knowledge and the link to the higher ladder of education (Freidson, 1986, p. 433, DiMaggio, 2009). With the creation of Royal Academy of Painting in France (1648), for instance, the ancient workshop masters had to become academics, professors, respectable people with wigs and ribbons, teaching the theoretical rules of their art, instead of showing the know-how to their trainees, looking for formal perfection instead of practical efficiency. 
Once academic art and artistic taste established themselves as a serious matter for the European bourgeoisie, during the $19^{\text {th }}$ century the wind of Romantic ideology blows from Germany in the opposite direction, rejecting academic knowledge and standardized rules and considering art no more in terms of a race for formal virtuosity, but as a matter of singular inspiration. Within a wider context of profound social changes seeing the consolidation of the modern nation-states system and the expansion of industrial revolution, the romantic aesthetic successfully imposes what becomes known as the typical iconography of the artist ${ }^{3}$, popularised through the diffusion of biographies tracing the exceptionality of its genius since early youth and emphasising the traits of mystery and magic emanating from his persona (Kris and Kurz, 1934, DeNora, 1995, Cook, 2009). The neat distinction drawn by Romanticism between the values of art and those of the external fields (l'art pour l'art) contributes to describe the artist's vocation more as an existential than as a working condition, in sharp opposition to the homo oeconomicus depicted by neo-classical economics, incarnation of the instrumentally rational self-interested actor maximizing his profits: disinterested in profit or recognition, and thus often misunderstood or underestimated in life, the authentic artist is exclusively voted to the expression of pure, transcendent art ${ }^{4}$.

The definition of artistic rules through an inversion of the dominant economic logics has been convincingly interpreted in terms of an entrepreneurial strategy functional to the valorisation of artistic work and the protection of the artistic occupation within a market economy system (Weber, 1992; Frederikson and Rooney; 1990, Moulin, 1992). From this perspective, the artist's adherence to the romantic ideal can be seen as responding to an "interest in disinterestedness" (Bourdieu, 1983), working as a proof of the authenticity of his work, not quantifiable in monetary terms, not determinable by market demand and thus differentiated from the cultural products overtly following a commercial logic. Besides artist's idolisation, other mechanisms concur to this process of social valorisation of artistic work within a market economy, as in the case of the sacralization of artistic canons, legitimised and reproduced within legitimated

${ }^{3} 3$. This mutation has been characterized by Nathalie Heinich (1993) in terms of a shift towards a "vocational regime of singularity".

${ }^{4} 4$. In both cases those we are talking about homines, as social conventions deemed feminine nature to be incompatible both with the heroic soul of the genial artist and the cold rationality of the public man (DeNora, 2000, Trasforini, 2007, Fineman and Dougherty, 2005). 
organisation with declared exclusive cultural aims (theatres, concert-halls, opera-houses, museums, Academies and Conservatoires).

Those organizations, reconfigured as "civic temples of the arts", are seen by the ruling elites as tools to define taste and acquire the knowledge needed to appreciate the great works of distinguished artists - marking social distinction between classes - (DiMaggio, 2009), but also to extend political control over civil society (Santoro, 2010).

During the $20^{\text {th }}$ century, the diffusion of radio, television, movies, and recorded music industries challenge the concepts of creation, reproduction, consumption, associated to artistic production by Romanticism. In order to re-establish the "aura" defining authenticity as the form of valuation of artistic work (Benjamin, 1955), the Marxist conceptual distinction between social work and alienated labour is applied to the artistic field, distinguishing between authentic artwork and standardised products of the "cultural industry", designed to exploit art as a commodified good meeting the utilities of mass consumers for entertainment (Horkheimer and Adorno, 1944). Denounced by critics of capitalism as a means to keep uneducated audiences socially passive, this distinction is ultimately adopted by mainstream economics, differentiating between an economy of unique cultural goods (including performing arts sectors, arts museums and cultural goods) and an economy of cultural and mass media industries (Benhamou, 2011). In the Thirty Glorious Years, within a context of growing legitimacy of Keynesian economics, the former is granted public assistance on the basis of its definition as a stagnant sector offering goods valuable for the society as a whole (Baumol and Bowen, 1966). Especially in those welfare states where the idea of a "wage society" finds greater social legitimacy (Castel, 1995), this also translates in forms of indirect support for artistic work (as in the stabilisation of personnel of public funded opera houses and museums or in the insertion of artistic disciplines in the curricula of national systems of education) (Casula, 2018.b).

The dawning of the post-industrial era opens up a macro-economic scenario seeing the slowdown of economic growth across OECD countries, leaving welfare systems with the dilemma of having to reconcile a decreased amount of public resources with popular pressure to maintain social expenditures (Pierson, 1996). Increasingly legitimised, neoliberal ideology recommends the adoption of managerial reforms aimed improving the efficiency and effectiveness of public policies and public sector organizations and to promote increasingly flexible labour markets, to encourage investment and economic growth while reducing unemployment. Those trends also affect the cultural and artistic sector, meanwhile invested 
by processes of declassification linked to the critiques raised by postmodern thought to the coercive power inherent to modern "grand narratives” (Lyotard, 1979), fostering cultural fragmentation and challenging the legitimacy of cultural authority of organizations and professional expertise in various fields of knowledge (Leicht, 2015; DiMaggio, 2009).

This significant changes have been read both in enthusiastic terms, considering the new possibilities offered to a boundless and interactive creativity both from an artistic or an economic point of view, or with a concerned look over the deskilling process often implied in the widespread artistic eclecticism or in a primarily instrumental consideration of culture. The empirical study of artistic work in contemporary societies can thus contribute to a better understanding of the ongoing changes in the systems regulating artistic production - in terms of organizational structures, social relations, norms and values - influencing the behaviour, experience, and identity of artists as workers and on the nature of work, as defined under contemporary capitalism.

\subsection{Art as a collective work, artists as ordinary workers}

A fundamental contribution to the study of artists' activity as a work, in the wider sense of the term - also embracing alienated labor -, has been offered by sociology since the second part of the $20^{\text {th }}$ century.

For Howard Becker (1951) this was firstly achieved through the study of dance musicians in Chicago during the late 1940s, defined as a deviant occupational group, with its own subculture, its own uses, language and norms. One of the most important was that musicians were representing themselves more (for "jazz" musicians) or less (for "commercial” musicians) as "artists" in the romantic sense, essentially different from the majority, the "squares". Becker does not take that ideology for granted and analyses the way it is socially constructed, both by the majority and the deviant group by a labelling work, generating a deviant subculture shared by the musicians and making them collectively exist, think and act as “special people”. In Art Worlds (Becker, 1982) he goes further in showing that art is the result of collective action in which the person identified as "the artist" is only one part of a much bigger system of interactions making artistic creation possible and determines it in many ways. Becker also addresses the issue of the social construction of the "art" category in a whole chapter dedicated to the conventional difference between "arts" and 
"crafts", identifying the main categories through which the distinction is built (unicity vs. reproducibility, intrinsic purpose vs. extrinsic purpose, etc.), and how it evolves in times (crafts becoming arts and vice versa). His work represents a major advance in the social study of arts, in that it deessentializes art, artistic work and artists.

Another fundamental contribution to the consideration of art as work, rather than a special and magical activity, is that offered by Pierre Bourdieu. Bourdieu (1971) insists on the fact that art is a kind of work which stands as its own retribution, done for one's own pleasure, for its intrinsic relevance. He locates art within the category of the "symbolic goods", with other mainly intellectual and symbolic productions, as literature, philosophy, sciences - to a certain extent - but also religion. The spaces of production of symbolic goods have a history, they are socially constructed and are the field of social battles and struggles for legitimacy between antagonist forces (conservatives vs. avant-garde). Those social spaces have their rules, and being an artist is firstly playing with those rules, as in any kind of occupational or professional space. As said in the previous paragraph, the romantic myth of the unique, lone, and free artist, "uncreated creator" is therefore interpreted as a strategy of distinction of the artist from the ordinary standard worker/laborer in the field of production.

From the historical and constructivist approach shared by Becker and Bourdieu, art is a human production - nothing more and nothing less. One can start to study art as any other social world, any field, any market or any organized system of production and distribution, considering the different levels of autonomy in the different parts of the art market, the different forms of arts with their respective history, the different countries and their ways to regulate work and employment. One can also study the entire spectrum of the art production and producers, from the famous and visible artists to the most ordinary ones, the ones who don't and won't ever get fame and money.

The condition of "ordinary artists" in different forms of arts was recently explored in the first issue of the journal Biens symboliques / Symbolic Goods, where the introductory chapter by Perrenoud and Bois (2017) tackles two main issues: (1) the fact that the immense majority of professional artists never gets rich or famous; (2) the recent generalization of norms and practices typical of artistic work as paradigmatic to the whole labour sphere. With reference to the first point, they argue that, despite the persistence of the romantic ideology of the individual talent and besides all the sympathetic and naïve images of bohemian artists, happy in their 
poverty and their fellowship, art worlds are (perhaps with sports worlds) among the most unequal social and professional spaces. The inequalities of revenues and reputation between two individuals doing the same job (painter, musician, dancer) are greater than in any other occupational space. And they are widely accepted in the artistic sector in the name of the differences of "talent" between individuals (Menger, 2002). As a consequence, most of professional artists do not reach the highest levels of recognition and remuneration and stay at the lower stages of the professional pyramid. Therefore, the huge majority of artists, in a certain way, contravenes the norm of individual exceptionality still ruling art fields. Ordinary artists draw for local stores advertisement, play music in weddings or bar-mitzvahs, write novels but don't sell it and make a living teaching literature. They are rarely in position to be taken as professional "artists" and, most of the time, they have to be humble and efficient service providers or somehow "failed artists". The second point made by Perrenoud and Bois considers how the practical organization and functioning of art worlds, reputed "atypical" during the $20^{\text {th }}$ century, is now extending to all the workspaces. Indeed, "gig economy" seems to become a common expression to designate different types of "work at task" that we could have thought largely outdated from the $21^{\text {th }}$ century, except for musicians accustomed to have "gigs" from one night to another.

Another typical trait of artistic work, the indetermination between domestic and workspaces, becomes paradigmatic of standard work in contemporary economies thanks to the pervasive diffusion of ICTs in the organization of personal and working lives. When an actor dines with a director, when two musicians go to a concert, when a painter goes to a colleague's exhibition, they are both in leisure and business. Due to the popularization of tools as laptops or smartphones and the spread of a new, cool, neat and friendly managerial style, people cannot always say if they are at work or not. This mutation comes with another one: the advent of work organization by "projects" which demands to build teams, pair people for a time and to move on to another project, which requires each time a maximum commitment. That's how theater, dance and music workers are used to do for each play, each performance, each album. But for engineers, accountants, teachers or social workers it's quite of a change. Finally, but crucially, the strong valorization of individual "human qualities" as "openness" or "creativity", impossible to objectivate, need always to be assessed by those who have the power to recognize it and create a context of permanent uncertainty about the value of the people and their work. That's what actors, dancers or musicians have known for decades: their 
work depends on the others' desire, especially that of "gatekeepers" (theater and venues directors, public or private donators, etc.) (Perrenoud and Bois, 2017).

2.3. The strength of the informal ties organizing artistic careers and labour markets

Another contribution of sociology in undermining commonplaces over artistic work is through the identification of the mechanisms regulating artistic labour markets. Some of the most relevant studies were developed in France and the UK within the sociology of profession approach, finding little visibility in Italy, despite the presence of interesting contributions. Bertolini and Cappellato (2010), for instance, illustrate how the arts sector employment market shows a number of specific features. First of all, it does not require formal qualifications or institutionalised paths to access its occupations. Professionalism within arts field is difficult to assess and there are not organisations capable of certifying this competence in an internationally accepted way. Artistic talent is usually attributed, on the one hand, to individual predispositions and, on the other, to the development of specific skills and techniques; technical proficiency, however, appears to be insufficient to define a person as an actor or a dancer; it is precisely the less technical attributes that ultimately define artistic talent within arts worlds. Furthermore, there are no clearly established rules to define career progression, as in organisational careers. Every employment transaction that is, every sign-up for a show - is specific and formally independent of both past engagements or future ones.

From those features, allocation mechanisms regulating artistic labour would seem to be ruled by the market, rather than by the organisation. Research studying artistic labour markets, however, shows that in reality they are structured by solid conventional rules, although more often informal in nature (Paradeise, 1998; Luciano and Bertolini, 2011, Casula, 2018b). On the same vein, artists' career patterns are not individualised as it might be expected, but show, on the contrary, a significant uniformity (Wagner, 2015). Talent becomes a negotiable resource on the market, through the judgement of quality expressed by the community of employers, artists and audiences, and it is this conversion which establishes individual artists' chances of being hired or the level of their pay. The definition of professionalism is based on precise rules of recognition and reputation within the artistic community, on a closed marketplace, a social 
space where impersonal recruitment and promotion rules are in place. Through these rules workers who are part of this employment market try to protect themselves from competition from workers outside of it, just as it happens in the occupational labour markets of organisations (Saglio, 1998).

Linking the analytical perspective on the study of professions to Bourdieu's (1995) concept of field, we can say that each artistic sector can be compared to a field representing the objective structures, the positions and distribution of resources that influence externally the interactions and representations of individuals. Experience in the field for individuals goes through the habitus, which is the immediate experience of individuals, the set of their perceptive and evaluative categories that structure individual choices and actions from the inside. These rules are the product of negotiations but appear to individuals as natural data. The field of the arts, in particular, «includes the whole universe of the arts world, made up of symbols, objects, systems of allocation, agents, institutions and economic organisations») (Santagata, 2004, p.7). Each artistic sub-field possesses certain characteristics in common with other sub-fields, but also has specificities requiring the reconstruction of the historical process by which it was produced and defined (Bourdieu, 1995). In fact, literature shows that different career patterns vary according to the specific arts sector, the subsector and the characteristics of the market and the organisations of each artistic world (Menger, 1999).

Thus, in order to enter the various fields, artists must overcome the specific entrance barriers and try to conquer dominant positions, also through the building of professional relationships. In the words of Paradeise (1998), studying actors in France, artists have to get the certification of "their own professionalism" from the community, in compliance with the specific rules of the field. Once they have entered the field, they can perpetuate the rules or try to subvert them using the resources they possess and the positions they occupy (Bourdieu, 1992). Rules do exist, however, to allow innovation to pass through: the field may modify its structure and, as a result of the pressure exerted, create new poles in a complex process of differentiation, often dominated by the absence of a unified aesthetic principle, allowing artists to be classified in a universal hierarchy of values (Santagata, 1994).

Another feature of artistic work concerns the fact that careers are often not conceived in traditional ways, that is, as ascending sequences of professional positions held over time. Moreover, positions cannot be ordered unidimensionally, as linked to parallel scales of pay, power and prestige: an artistic professional path may in fact be ascending on one scale 
and descending on another. It is however possible to talk about artistic careers on an external market, if we use Becker's perspective (1982), considering it as a collection of a series of professional positions held over time, with no reference to a specific order. In this respect, several authors notice how the building of a career in the arts sector can be associated to creating a financial portfolio, with the risk being hedged by investing in several segments of the employment market. Indeed, literature talks of "portfolio careers" of artists (Gold and Fraser, 2002; Menger, 1999; Faulkner, 1983): here artists' ability in building a career lies in a careful mixing of occupations (e.g. actor and teacher), in various sectors (e.g. movies and advertising) and with different clientele (e.g. one-off and recurring customers). In this process, it becomes fundamental for artists to widen membership to a variety of networks, in order to increase the chances of future engagements and thus reduce the uncertainty and risk of having to deal with periods of unemployment.

In Italy, where the formal regulation of artistic labour market is very low, one of the main strategies carried out by artists is a dual career path, with one lane in the arts sector and another in a different sector. This strategy is chosen by those who, despite talent and engagement, do not manage to economically survive only on artistic revenues (due to a difficult work-life balance or unfortunate chances or choices), but still consider the artistic occupation as what primarily defines their professional identity. They thus have a second stable line of employment, sometimes distant from the arts sector and often part-time, granting them an income but leaving them enough time to perform professionally in a sector offering a greater symbolic gratification. A second strategy is that of a dual career within the arts sector (Luciano and Bertolini, 2011). This strategy may be realised through extensive diversification across several artistic sectors (e.g. theatre and television), or through intensive diversification, working in the same sector but doing more than one profession (e.g. actor and director, dancer and dance teacher, etc.). Extensive diversification is a good strategy to reduce economic risks and limit discontinuity of employment, but it requires the development of several specific skills (Bertolini and Maggiora, 2018). One interesting solution is that identifying contiguous sectors of activity in which to carry out professions that are in some way related to one's own, but better paid. In extensive diversification, a "Chinese box" mechanism is activated, where one door seems to open another. In this respect, the world of advertising and television have widened the arena of opportunities, especially for artists of the theatre and movie sectors. 
Dual career paths, portfolio careers, project-based work are naturalised as specific features of the artistic labour market by the majority of artists, who seem to experience those features less problematically than workers of other economic sectors (although consequences in their private lives may be or become quite significant): in some way, precariousness and insecurity are reconfigured as the price to be paid for doing a job that one enjoys doing.

\subsection{The key role of the state in the regulation of artistic work}

A further contribution of sociology in subverting common sense over artistic work is offered by the assessment of the role of the state in regulating artistic labour markets, often depicted as a model of de-regulated neo-liberal markets. Uncertainty, competition and wide inequalities are indeed presented as inherent to artistic work (Menger, 1999) and the arts increasingly «command attention as a 'laboratory' for the current forms of labour market deregulation» (Ducret et al., 2017, p. 239). Thus, analyzing how the national political and institutional contexts influence artist work may appear as secondary. Nevertheless, as Norbert Elias (1991) or Pierre Bourdieu (2013) pointed out in their seminal works on Mozart or Manet, the possibility of being an artist and making a living as such crucially depend on the political and institutional settings within which artists are embedded. More than just control or dependent variable - to use a statistical metaphor (Menger, 1999) - the state's commitment in cultural production has a crucial impact in the various ways of working within art fields. Indeed, the possibility of relying or not on the support of a non-marketdriven institution (state or foundations) directly influences risk-taking in terms of artistic and professional choices, for those trying to make a living with art (Kleppe, 2017).

As Vincent Dubois (2015, p.460) notices, the way contemporary states sustain (or not) cultural production is deeply «linked with the general renewal of state intervention that consisted in the making of democratic welfare states after World War II»). Cultural policy regimes cannot be reduced to a simple variation in the traditional patronage between the State and artists. They «reflect the patterns of the national cultural fields, that is to say their socio-economic structure, their internal hierarchies and the conceptions of art and culture that prevail within them» (Dubois, 2015, p.460) and have to be analyzed per se. In national spaces where liberal political thinking deeply shaped institutions since 1945 - as Chile (Moyano, 
2017), the USA (Binkiewicz, 2004) or Switzerland (Thévenin and Moeschler, 2018) -, state intervention in cultural affairs is seen as illegitimate, except if cultural industries are considered as a key economic sector for national wealth - as in the UK (Bouquillion, 2012). The market economy logic is here seen as the most legitimate way to regulate artrelated labour markets. In other national contexts, where welfare regimes prevailed after the WW2, the state is seen as the main guardian of art worlds' independence vis à vis economic markets. State institution appears thus more legitimate to support cultural actions and artistic propositions as in France (Dubois, 1999) or Norway (Mangset et al., 2012). Public funding can also be subject to favor some particular culture in multicultural contexts. This has been the case over the past twenty years in Belgium (Lowies, 2013), Switzerland (Thévenin and Moeschler, 2018) and Scotland (Galloway and Dunlop, 2007): in such national/regional contexts, the issue of the right to cultural expression has been the principle of an increased support from local and regional political bodies to the cultural sector, to counter a vision solely focused on economic profitability (Galloway and Dunlop, 2007).

Such a variety of cultural policy regimes deeply shapes the concrete working practices and representations of artistic workers, especially those who are at the lower level of the professional hierarchy, as ordinary artists (Perrenoud and Bois, 2017), mainly ruling their careers in local contexts. Indeed, more than international stars, ordinary artists are more deeply embedded within institutional regulations and national employment frames, asking them to declare their activities in order to claim unemployment benefits or achieve other forms of recognition. Cross-national comparative studies on artistic employment pointed out that cultural policy regimes impact on the day to day work of most of the artistic workers by shaping the legitimate "bundle of tasks" (Hughes, 1971), the social division of artistic labor the work-related political behaviors and the forms of unionism (Umney, 2016). International comparison is indeed one of the main tools helping to point out how far «the brave new world of creative work, both celebrated and strongly criticized by several scholars, is not a 'law of nature'» (...): «the analytical insights from comparative cultural sociology, shows how both cultural policy and management strategies strongly affect labour conditions and economic risk management for the single artist» (Kleppe, 2017, p. 61).

Thanks to the few international studies on this topic, two main dimensions can be distinguished to frame the analysis of how policy and welfare approaches to cultural goods impact artistic work: (1) if the public 
institutions directly handle the regulation of artistic employment or not and, if so, (2) how such regulation occurs. The case of musical work provides a good illustration of our first analytical perspective (Perrenoud and Bataille, 2017). In line with the strong state involvement in cultural sphere, France is well-known for having a special unemployment system ruled by the state for living arts performers and technicians - the so-called intermittence system (Grégoire, 2013; Langeard, 2013). In this context, playing music on stage is the main objective for musicians aiming to collect enough declared working hours to qualify for the "intermittent" status. This leads to a strong career differentiation between those who play music to make a living and music teachers - since teaching time is not eligible for intermittence (Perrenoud, 2007). In Switzerland, where this type of system is not available for musicians, teaching represents the livelihood for most of them (Perrenoud and Bataille, 2019). Differently from their colleagues in France, those defining themselves as musicians in Switzerland integrate teaching within the legitimate bundle of their professional tasks. Thus, regulation variation of artistic activities at a macro level directly impacts the borders defining professional groups, the social division of labour and the inequalities related to inherited cultural capital and gender among musicians' professional space (Perrenoud and Bataille, 2017). Such variations also hold strong implications on how arts workers claim for salaries, better working conditions or act like a political force through unionism, as the comparison between London and Paris independent musicians point out (Umney, 2016).

A possible typology for our second analytical perspective - i.e., how the various types of regulation impact work practices in artistic labour markets - is offered by the work of Kleppe (2017) on how actors and companies deal with economic risk and artistic innovation in the UK, Netherlands and Norway. Two main ways of funding can be distinguished: State-related institutions fund artistic production either on a project-basis - as it is the case with the Netherlands - or by providing enough recurrent funds to finance permanent jobs for actors - as it is the case in Norway. In the project-based funding system, the economic and artistic risks are collectivized at a meso-level, from the company, the creative collective or other equivalent organization, getting the funding for a given project (Kleppe, 2017, p. 60). However, maintaining a fruitful work dynamic throughout several projects may represent a challenge affecting relations between those identified as project leaders and the others. In the permanent-based funding system, risks are more institutionalized (Kleppe, 2017, p. 60): in the case of artists financed by permanent contracts (as 
many actors in most nationally renewed theaters in Norway) they can more easily dare radically creative experiments, without worrying about economic consequences. However, often the slow and heavy bureaucratic structure of state supported art factories may represent a sort of "iron cage", avoided when local arrangement may ensure the implementation of more horizontal and dynamic workspaces (Mangset et al., 2012).

\section{The contribution of this special issue to the debate}

The framework drafted in the previous paragraphs allows us to disentangle the ambiguity of the debate celebrating artistic work as paradigmatic of the creative economy. In disguising the similarity of the occupational conditions of creative workers with those of ordinary artists under the attractiveness of the professional status recognised only to a reduced minority of artists and in interpreting work fulfilment mainly in terms of individual creativity and self-worth, the debate underestimates the relevance of historical and institutional factors in defining the conditions and mechanisms allowing artists to enter and endure in, or to be banned or rejected from, their respective labour markets. This special issue, on the contrary, aims to contribute to the development of a sociology of artistic work attentive to global changes and the socio-institutional structures within which it is embedded, in the pathway of the tradition outlined above.

Out of seventeen abstracts submitted, six were selected referring to their coherence with the thematic focus of the special issue, theoretical and methodological soundness, the variety of art worlds considered and the coverage of different geographical areas. The topics discussed include the role of spatiality on artists work; historical changes in the relation between artists social image and their actual working conditions; the approaches adopted by public and private organizations in the regulation of artistic work; the occupational strategies embraced by artists to endure within artistic labour markets; the conflicting nature of the mechanisms required to artists in the making of their career. Geographical areas covered - in most cases grounded in a subnational empirical research, but inserted within a picture of national regulation strongly influenced by wider global neoliberal trends - include Argentina, France, Italy, Portugal, Spain.

The chapter from Vera Borges and Luisa Veloso ("Emerging patterns of artistic organizations in Portugal: A three case studies analysis") deals with the post 2008 crisis context of austerity which stroke the country and its impact on artistic work. Examining the recent history, the authors tackle 
different types and forms of artistic and cultural organisations as they evolved since the 1980s-90s, shifting from a post-dictatorship socialdemocratic framework to a gradually more deregulated market-oriented one, hit by the 2008 global financial and economic crisis. Borges and Veloso walk explicitly in P.-M. Menger's footsteps in considering nowadays artist as "the future's worker". The three cases studies they present (Teatro Aberto - Novo Grupo, Lavrar O Mar, and Latoaria) rely on accurate interviews and document analysis. Drawing on collected evidence, the authors argue that the organisation of work and employment in the cultural and artistic sector has always represented a major issue, whose administration largely depends on prevailing socio-economic conditions, to which organizations necessarily have to adapt in order to professionally survive, more recently adopting new collaborative arrangements, in the attempt to resist general precariousness.

Sarah Lahasky's article ("Municipal Sponsorship and Musical Work in Argentina: Ensemble Institutionalization in a Neoliberal Economy") is based on an ethnographic case-study focussing on a group of guitarists who, thanks to the development of local cultural policies, are employed by a small municipality in Argentina (Guaymallén). Lahasky's analysis crosses three fundamentals issues. First, she points out that artistic work is not inherently precarious and uncertain, occupational features strongly depending on the socio-political context. The Guaymallén municipality decided to employ on a regular basis a group of musicians to maintain a local cultural activity in a national context of strong economic deregulation. Second, it shows how this kind of investments may have a twofold aim: policies supporting local culture may grant artists more decent working and living conditions, while also boosting city attractiveness and the local economy. Nevertheless, the article also points out to the dilemma that musicians employed by the municipality have to face, in seeing their artistic autonomy limited by the assignment of formal and administrative requirements and tasks.

Isabelle Mayaud's and Laurent Jeanpierre's contribution ("Visual artist's plural forms of activity and trade-offs in a French region") considers how visual artists in the Grand Est region in France cope with the structural precarity affecting their artistic labour market - worsened by global legitimation of neoliberal theories celebrating self-employment as the new paradigm of work. The paper is based on the analysis of data from surveys commissioned by the regional branch of the French Ministry of Culture and three territorial networks of contemporary art of the region. Authors show how, in face of the average low economic returns derived 
from their artistic work - comparatively lower for female artists -, visual artists adopt a series of differentiated practices of self-employment, either in coherent or unrelated sector. For the great majority of respondents those activities represent an obstacle to the construction and development of their artistic career and detrimental to the conduction of a family life, especially in the case of female artists. One of the ways in which family and working time become blurred, rather than balanced, comes from the confusion of visual artists between place of residence and space to work, often coinciding because of the need to reduce the economic costs linked to works' production and exhibition. Other strategies adopted by visual artists to cope with the low economic returns and the precariousness of their artistic activity include recourse to welfare state policies or reliance on family economic resources. Mayaud and Jeanpierre also offer interesting evidence on how visual artists frame their artistic identity: while the great majority shares the occurrence of an early desire to become an artist, they do not associate this trait to the romantic archetype. Artists refer to their activity more in terms of commitment and work, than in terms of vocation. The diversified ways of presenting and self-defining their activity reveal a multifaceted working identity linked to the variety of tasks fulfilled and to the need of playing different roles depending on the working environment.

Also Marta Casals' paper ("Artistic-professional strategies in the music sector. The case of the jazz scene in Barcelona") deals with the ways in which artists cope with the challenges faced in contemporary artistic labour markets. The focus is here on the strategies adopted by jazz musicians steadily active in the lively cultural scene of the capital city of the Spanish region of Cataluña. Casals' argument is mainly based on the qualitative analysis of a selection of the nearly 100 semi-structured and informal interviews collected for her $\mathrm{PhD}$ thesis. The accounts of the jazz musicians interviewed confirm the relevance of those mechanisms already identified by the literature as useful in entering and enduring within artistic labour markets: affiliation in music schools or other sites for artistic training, activating those circles of contacts among peers sharing a sense of belonging to community of practices and conventions, facilitating cooperation based on reciprocity rules; the establishment of a good reputation among colleagues, translated into involvement in further engagements, fostering the development of a personal career. However, musicians' experiences also tell us about the new commercial logic requiring them a self-management of their activities and a self-branding of their identity through the social media, establishing a more direct relation with the audience. Further endeavors include artists' production of music in 
physical audio recording formats, increasingly supplanted by digital formats in the market, but still symbolically relevant to affirm their identity to the outside (as an artistic equivalent of a "business card"). The increasing fragmentation of time to be dedicated to a growing variety of administrative and marketing activities needed for the promotion of their artistic production paradoxically risks to block its very source, leading artists to experience a loss of control on the time needed to devote to their work the necessary concentration and energies.

The issue of the resources needed by artists to cope with the labour market and, in particular, of the individual sustainability of the costs of working spaces are further explored in the article by Damiano Razzoli, Stefano Rodighiero, Lorenzo Mizzau and Fabrizio Montanari ("Need for space. How artists rely on space to face precarious work conditions"). Based on a qualitative study on young artistic workers in the Italian city of Reggio Emilia, the authors starts noticing how artistic workers have to deal with two apparently contrasting forces: on the one side, the quest for freedom and autonomy, on the other side the need of support to overcome the negative consequences of extremely skewed, unpredictable, and fastchanging labor markets. In the so-called "platform capitalism" or "gig economy", workers are loosely affiliated with organizations and move from one project to another, depending on work opportunities popping up "on the fly", leading to increased de-materialization and de-spatialization of work. The article investigates on how space could be harnessed by artistic workers to sustain their professional development and employment. Drawing on the analysis of collected evidence, it identifies three functions through which space can serve as a personal compass mitigating the effects of the precarization of work. By exerting an anchoring function, space satisfies a need for operation in terms of a physical setting where to get things done (production) and improving competences (learning); through a framing function, space satisfies a need for sociality in terms of fostering the building of relationships (networking) and the sharing of tools and knowledge (experimentation) that support artistic workers' creativity; finally, by exerting a belonging function, space satisfies a need for identity translated in appreciation from other artistic workers (recognition) and a feeling of belonging to a workplace and a broader urban context (attachment).

The socio-historical perspective on the development of the Italian theatrical sector adopted by Marco Serino in his essay ("Continuity, change and transitions of artistic professions in the Italian theatre industry") appears fundamental in order not take for granted the association between 
artistic work and precarious or uncertain working conditions. The author shows how the Italian theater sector, after centuries of weak institutionalization, has known during the $20^{\text {th }}$ century a strong movement of stabilization and standardization regarding working conditions, funding, setting of acting academies and stable theatres. Such institutionalization of the theatrical sector has been possible mainly because of the large public investments at national or local level. Since the 1980s, however, with the crisis of welfare state systems and the rise of neo-liberally oriented policies, the theatre sector experiences - even more than other sectors - a downsizing of public support and a general worsening of employment conditions. Far from being natural "laboratories of flexibility", also artistic professions and artistic workplaces appear to be experiencing hard times in face of the ongoing restructuring of contemporary capitalism, although differently managed in the various organizational or institutional contexts.

\section{Conclusions. Forerunners on the move: the status of artistic workers under contemporary capitalism}

From what argued in the previous paragraphs and in the following essays, we can conclude that, although some of its features appear to be forerunner of contemporary labour markets, artistic work is also experiencing profound changes, following the ongoing transformation of the nature of work in contemporary capitalism. The idealised vision of the romantic artist, despite its distance from the reality of most of arts workers, also offered "ordinary artists" the advantages of a socially recognised professional role, grounded on their membership to art worlds defined by specific autonomous rules, skills and jargons, enhancing the economic value of artistic production in the market on the basis of its intrinsic worth. Membership within art worlds was fundamental for artists to acquire the set of conventions facilitating collective action, creating the sense of belonging to a community of practice, offering reputational legitimation and certification of skills and authenticity: all aspects facilitating artists' integration and permanence within artistic labour markets. From this perspective, art worlds represented for artists a sort of "centre of gravity" in the organization of their production or in the definition of their professional identity, either expressed in a more canonical or unconventional way, and a shelter against the market's whims, often further reinforced by public policies supporting cultural and artistic production. 
Today those features seem to maintain their relevance in the regulation of artistic work in contemporary capitalist societies, but their influence is weakened by the increasing legitimacy and influence of paradigms of production that - as in the case of the "creative economy" debate - apply the logic of market regulation to the wider sphere of work, including artistic work. Not differently from other workers comprised within the "creative class", artists are asked to dedicate an increasing amount of their time to self-marketing practices hard to reconcile with the requirement concentration, practice, dedication, devotion - defining a the ethics of a well done job (Sennett, 2008). From this perspective, the value of artwork tends to be ultimately decreed by its market value, ruled by consumers preferences. Artists feel therefore forced to dedicate a significant part of their time to the individual self-marketing of their work and self-branding of their identity, engaging in an increasingly non mediated relation with their audiences, in the aim of capturing an enlarged public of "followers" through the use of digital social platforms.

A problematic consequence of this ideological neoliberal shift is that it frames individual competition as an enjoyable and morally legitimated end. The "creative age" worker is seen as primarily moved by a competitive interest in self-promotion. The parables of the success stories developed in the last thirty years in the ICT sector have played a big role in promoting the social figure of the "cool creative entrepreneur", celebrating the myth of two guys in a garage wearing T-shirts and devising products successfully imposed at the global level. The basic idea is that everyone has a Steve Jobs in a corner of his/her head, they just have to let him out, express their talent in the healthy competition and, hopefully, fame and money will come. This new social and even anthropological model of worker, while presenting creative work as empowering artists, urges them to stand out selling their precarious subjectivities as more valuable than that of others (Turrini and Chicchi, 2014), becoming at the same time traders and commodities, exploited and self-exploiters (Boltanski and Esquerre, 2017).

Those considerations show how the study of artistic work in contemporary societies can be seen as fruitfully contributing to the sociology of work at two different levels: at a more sectorial level, focussing on changes occurring within the organization of work within art worlds; at a more general level, as a useful case to reflect over the wider reconfiguration investing the nature of work and employment relations in contemporary globalised capitalist societies.

When Sociologia del lavoro was launched - over forty years ago - it had among its aims that of allowing Italian sociology to catch up with the most 
recent international developments in the field of sociology of work ${ }^{5}$. The monographic issues of its first ten years were particularly relevant in laying down the foundations of national debates within a wider international background. The one dedicated to artistic work presented articles by some of the most well-known scholars in the field ${ }^{6}$. However, differently from other topics covered by the journal in the same period, the study of artistic work did not develop into dedicated streams of national research on sociology of work. We hope this special issue will contribute to the relaunching in national debates of this field of study, fraught with fruitful insights for the sociology of work and professions.

\section{References}

Baumol W.J., Bowen W.G. (1966). Performing Arts, the Economic Dilemma: A Study of Problems Common to Theatre, Opera, Music, and Dance. New York: Twentieth Century Fund.

Becker H.S. (1963). Outsiders, New York: Free Press.

Becker H.S. (1951). The Professional Dance Musician and His Audience. American Journal of Sociology, 57(2): 136-144.

Becker H.S. (1982). Art Worlds. Berkeley: University of California Press.

Becker H.S. (1986). Mondi artistici e tipi sociali. In: Luise A., Minardi E. (eds.) Il lavoro artistico, Sociologia del lavoro, 25: 39-53.

Bellini P.P. (2005). Pronipoti di Mozart. Modelli, teorie, condizioni delle professioni musicali in Italia. Firenze: SEF.

Benhamou F. (2011). L'économie de la culture. Paris: La Decouverte.

Benjamin W. (1998). L'opera d'arte nell'epoca della sua riproducibilità tecnica. Arte e società di massa. Torino: Einaudi (original edition: Das Kunstwerk im Zeitalter seiner technischen Reproduzierbarkeit. In: W. Benjamin, Schriften, 1955 Suhrkamp Verlag, Frankfurt am Main).

Bertolini S., Cappellato V. (2011). Professionisti creativi: i percorsi di carriera nello spettacolo dal vivo. In: Luciano A., Bertolini S. (eds.) Incontri dietro le quinte. Imprese e professioni nel settore dello spettacolo, Bologna: Il Mulino.

${ }^{5}$ 5. On this point, see Michele La Rosa, directing the journal for 40 years, interviewed by Barbara Giullari for the SISEC Interviste section (\#1/2018), in the website of the Italian Association of Economic Sociology (SISEC, www.sisec.it).

${ }^{6} 6$. The issue, edited by Luise and Minardi, collected essays of H. Becker, A. Hennion, P.-M. Menger, R. Moulin, translated in Italian from their original version published in Sociologie du travail, and original essays by Italian scholars (L. Altieri, M. Bianchi, F. Caristi, M. De Marinis, A. Generoso, P. Gurisatti, A. Luise, E. Minardi, G. Panunzio, G.P. Prandstraller, B. Tellia, M. Tirelli), covering a variety of artistic occupations (painters, poets, musicians, actors, artistic craftsmen and managers, voice actors in movies, artistic managers, fashion designers). 
Bertolini S., Maggiora A. (2018). Le figure professionali in ambito musicale in Italia: tra precarietà e nuovi percorsi di imprenditorialità. Quaderni Rassegna Sindacale, 17(4): 81-101.

Binkiewicz, D.M. (2004). Federalizing the Muse: United States Arts Policy and the National Endowment for the Arts, 1965-1980. Chapel Hill : Univ of North Carolina Press.

Boltanski L., Esquerre A. (2017). Enrichissement : une critique de la marchandise, Paris: Gallimard.

Bouquillion P. (2012). Creative economy, creative industries : des notions à traduire. SaintDenis: Presses universitaires de Vincennes.

Bourdieu P. (1971). Le marché des biens symboliques. L’Année sociologique, 22: 49-126.

Bourdieu P. (1980). Questions de sociologie. Paris: Minuit.

Bourdieu P. (1992). Les règles de l'art. Genèse et structure du champ littéraire. Paris: Seuil.

Bourdieu P. (2013). Manet, Une révolution symbolique. Cours au collège de France (19982000). Paris: Seuil.

Boutang Y.M. (2011). Cognitive Capitalism, Polity Press, Cambridge-Malden (original edition: 2007, Le Capitalisme cognitive. Paris: Éditions Amsterdam).

Burke P. (1979). L'artista: momenti e aspetti. In: AA.VV. (eds.) Storia dell'arte italiana, II, Torino: Einaudi.

Castel R. (1995). Les métamorphoses de la question sociale. Une chronique du salariat. Paris: Fayard.

Casula C. (2018.a). Diventare musicista. Indagine sociologica sui Conservatori di musica in Italia. Mantova: Universitas Studiorum.

Casula C. (2018.b). Torn Between Neoliberal and Postmodern Trends, Corporatist Defence and Creative Age Prospects: The Ongoing Reshaping of the Classical Music Profession in Italy. Cambio: Rivista Sulle Trasformazioni Sociali, 8(16): 71-82. DOI: 10.13128/cambio-23296.

Cloonan M., Williamson J. (2017). Introduction. Popular Music and Society, 40(5): 493498.

Cook N. (2009). The economics and business of music. In: Harper Scott J.P.E., Samson J. (eds.) An Introduction to Music Studies. Cambridge: Cambridge University Press.

DeNora T. (1995). Beethoven and the Construction of Genius: Musical Politics in Vienna, 1792-1803. Berkeley: University of California Press.

DeNora T. (2000). Corpo e genere al piano. Repertorio, tecnologia e comportamento nella Vienna di Beethoven. Rassegna italiana di Sociologia, 41(2): 165-188. DOI: $10.1423 / 2537$

DiMaggio P. (2009). Organizzare la cultura. Imprenditoria, istituzioni e beni culturali, Bologna: Il Mulino.

Dubois, V. (1999). La politique culturelle. Genèse d'une catégorie d'intervention publique. Paris: Belin.

Dubois V. (2015). Cultural Policy Regimes in Western Europe. In: Wright J.D. (ed.), International Encyclopedia of the Social \& Behavioral Sciences (II edition). Amsterdam: Elsevier.

Ducret A., Glauser A., Moeschler O., Rolle, V. (2017). Introduction: Artistic Work as a “Laboratory” of Labour Market Deregulation?. Revue Suisse de Sociologie, 43(2): 239252. DOI: 10.1515/sjs-2017-0014.

Elias N. (1991). Mozart, sociologie d'un génie. Paris: Seuil (original edition: Mozart: Zur Soziologie eines Genies, 1991, Frankfurt am Main: Suhrkamp).

Faulkner R.R. (1983). Music on demand. New Brunswick: Transactions Books. 
Fineman M., T. Dougherty (2005). Feminism Confronts Homo Economicus: Gender, Law, and Society. Ithaca NY and London: Cornell University Press.

Florida R. (2002). The Rise of the Creative Class: And How It's Transforming Work, Leisure, Community and Everyday Life. New York: Basic Books.

Frederickson J., Rooney J.F. (1990). How the Music Occupation failed to become a Profession. International Review of the Aesthetics and Sociology of Music, 21(2): 189206.

Freidson E. (1986). Les professions artistiques comme défi à l'analyse sociologique. Revue française de sociologie, 27(3): 431-443.

Galloway S., Dunlop S. (2007). A Critique of Definitions of the Cultural and Creative Industries in Public Policy. International Journal of Cultural Policy, 13(1): 17-31. DOI: 10.1080/10286630701201657.

Giorgiantonio C., Rizzica L. (2018). Il lavoro nella gig economy. Evidenze dal mercato del food delivery in Italia. Questioni di Economia e Finanza. Occasional papers, Banca d'Italia, n.472.

Gold M., Fraser J. (2002). Managing self-management: successful transitions to portfolio careers, Work Employment and Society, 16(4). DOI: 10.1177/095001702321587370.

Grégoire, M. (2013). Les intermittents du spectacle : enjeux d'un siècle de luttes. Paris: La Dispute.

Heinich N. (1993). Du peintre à l'artiste. Paris: Minuit

Horkheimer M., Adorno T. (2010). Dialettica dell'illuminismo. Torino: Einaudi (original edition: 1947, Dialektik der Aufklärung Philosophische Fragmente. Amsterdam: Querido Verlag).

Howkins J. (2001). The Creative Economy: How People Make Money from Ideas. London: Allen Lane.

Hughes E. (1971). The sociological eye: Selected papers. New York: Aldine.

Kleppe B. (2017). Theatres as risk societies: Performing artists balancing between artistic and economic risk. Poetics, 64: 53-62. DOI: 10.1016/j.poetic.2017.08.002.

Kris E., Kurz O. (1989). La leggenda dell'artista. Torino: Bollati Boringhieri (original title: Die Legende wom Künstler: Ein historischer Versuch. Wien: Krystall Verlag, 1934).

Lahire B. (2015). Ceci n'est pas qu'un tableau: Essai sur l'art, la domination, la magie et le sacré. Paris: La Découverte.

Laillier J. (2017). Entrer dans la danse. L'Envers du Ballet de l’Opéra de Paris. Paris: CNRS.

Langeard C. (2013). Les intermittents en scènes. Rennes: Presses Universitaires de Rennes.

Lehmann B. (2005). L'orchestre dans tous ses éclats. Paris: La Découverte.

Leicht K. (2015). Market fundamentalism, cultural fragmentation, post-modern skepticism, and the future of professional work. Journal of Professions and Organization, 1(3): 115. DOI: $10.1093 /$ jpo/jov006.

Lowies J.-G. (2013), La diversité culturelle. Repères, 3: 4-19.

Luciano A., Bertolini S. (eds.)(2011). Incontri dietro le quinte. Imprese e professionisti nel settore dello spettacolo. Bologna: Il Mulino.

Luise A., Minardi E. (eds.)(1986). Il lavoro artistico, Sociologia del lavoro, 25.

Lyotard J.-F. (1979). La Condition postmoderne. Rapport sur le savoir. Paris: Editions de Minuit.

Mangset P., Kleppe B., Røyseng S. (2012). Artists in an Iron Cage? Artists' Work in Performing Arts Institutions. The Journal of Arts Management, Law, and Society, 42(4): 156-175. DOI: 10.1080/10632921.2012.727773.

Menger P.-M (2002). Portrait de l'artist en travailleur. Paris: Seuil. 
Menger P.-M. (1999). Artistic labor markets and careers. Annual Review of Sociology, 25: 541-574. DOI: 10.1146/annurev.soc.25.1.541.

Moulin R. (1967). Le marché de la peinture en France. Paris: Minuit.

Moulin R. (1986). Dall'artigiano al professionista: l'artista. In: Luise A., Minardi E. (eds.) Il lavoro artistico. Sociologia del lavoro, 25: 55-71.

Moulin R. (1992). L'artiste, l'institution et le marché. Paris: Flammarion.

Moyano C. (2017). Assembling the Self: Biographical Narratives of Chilean Musicians [Thèse de doctorat en sciences sociales]. Lausanne: Université de Lausanne.

Murgia A., Maestripieri L., Armano E. (2016). The Precariousness of Knowledge Workers: Hybridisation, Self-employment and Subjectification. Work Organization, Labour \& Globalisation, 10(2): 1-8. DOI: 10.13169/workorgalaboglob.10.2.0001.

Paradeise C. (1998). Les comédiens. Professions et marchés du travail. Paris: Presses universitaires de France.

Perrenoud M. (2007). Les musicos. Enquête sur des musiciens ordinaires. Paris: La Découverte.

Perrenoud M., Bataille P. (2017). Artist, Craftsman, Teacher: “being a musician” in France and Switzerland. Popular Music and Society, 40(5): 592-604. DOI: 10.1080/03007766.2017.1348666.

Perrenoud M., Bois G. (2017). Ordinary artists: From Paradox to Paradigm?. Biens symboliques / Symbolic Goods, 1:2-35.

Perrenoud, M., Bataille, P. (2019). Vivre de la musique? Lausanne: Antipodes.

Pierre C. (1990). Le Conservatorie national de musique et de déclamation. Paris: Imprimerie Nationale.

Pierson P. (1996). The new politics of the welfare state. World Politics, 48(2):143-179. DOI: 10.1353/wp.1996.0004.

Prandstraller G. (1986). La produzione artistica nelle arti visive. In: Luise A., Minardi E. (eds.) Il lavoro artistico. Sociologia del lavoro, 25: 23-37.

Saglio J. (1998). Les comédiens, profession et marchés du travail, Travail et Emploi, n.77.

Santagata W. (2004). I beni della creatività tra arte contemporanea e moda, Dipartimento di Economia “S. Cognetti De Martiis", Working Paper n. 2,

(https://www.fondazionesantagata.it/wp-content/uploads/2_WP_Ebla-2.pdf, last access: 12/05/20).

Santagata W. (ed.)(1994). Economia dell'Arte. Istituzioni e mercati dell'arte e della cultura. Torino: Utet

Santoro M. (2010). Constructing an Artistic Field as a Political Project: Lessons from La Scala. Poetics, 38(6): 534-554. DOI: 10.1016/j.poetic.2010.10.001.

Sennett R. (2008). The Craftsman. New Haven, CT: Yale University Press.

Simmel G. (1911). Philosophische Kultur. Leipzig: Klinkhardt.

Tessarolo M. (2014). Il lavoro dell'artista come professione. Cambio: Rivista Sulle Trasformazioni Sociali, 4(7): 75-88. DOI: 10.13128/cambio-19235.

Thévenin O., Moeschler O. (2018). The Changing Role of the Cultural State: Art Worlds and New Markets. A Comparison of France and Switzerland. In: Alexander V. D., Hägg S., Häyrynen S., Sevänen E. (eds.), Art and the Challenge of Markets, vol. 1. London: Palgrave Macmillan.

Trasforini M.A. (2007). Nel segno delle artiste. Bologna: Il Mulino.

Turner V. (1974). Liminal to Liminoid. In: Play, Flow, and Ritual: An Essay in Comparative Symbology. Rice University Studies, 60(3): 53-92. DOI: 10.5433/21766665.2012v17n2p214. 
Turrini M., Chicchi F. (2014). Precarious subjectivities are not for sale: the loss of the measurability of labour for performing arts workers. Global Discourse, 3(3-4): 507-521. DOI: $10.1080 / 23269995.2014 .885167$.

Umney C. (2016). The labour market for jazz musicians in Paris and London: Formal regulation and informal norms. Human Relations, 69(3): 711-729. DOI: 10.1177/0018726715596803.

Wagner I. (2015). Producing Excellence. The Making of Virtuosos. New Brunswick: Rutgers University Press.

Weber M. (1921). Die rationale und soziologischen Grundlagen der Musik. Munich: Drei Masken Verlag.

Weber W. (1992). The Rise of Musical Classics: A Study in Canon, Ritual and Ideology. Oxford: Oxford University Press.

Weber W. (1994). Mass Culture and the Reshaping of European Musical Taste, 1770-1870, International Review of the Aesthetics and Sociology of Music, 25(1): 175-190.

Zolberg V.L. (1990). Constructing a Sociology of Arts. Cambridge: Cambridge University Press. 